\title{
The Phenomenon of Physicology Senior High School Education: Relationship of Students' Attitudes toward Physic, Learning Style, Motivation
}

\author{
Maison $^{1}$, Astalini ${ }^{1}$, Darmaji $^{1}$, Dwi Agus Kurniawan ${ }^{1, *}$, Rahmat Perdana $^{1}$, Lika Anggraini ${ }^{2}$ \\ ${ }^{1}$ Faculty of Teaching and Education, Universitas Jambi, Indonesia \\ ${ }^{2}$ Program Pascasarjana, Pendidikan Matematika dan Ilmu Pengetahuan Alam, Universitas Jambi, Indonesia
}

Received August 2, 2019; Revised September 23, 2019; Accepted September 27, 2019

Copyright $\bigcirc 2019$ by authors, all rights reserved. Authors agree that this article remains permanently open access under the terms of the Creative Commons Attribution License 4.0 International License

\begin{abstract}
This article presents researches conducted at Muaro Jambi high School 5, at Muaro Jambi High School 10, at Jambi City High School 5 and Jambi City High School 10 about the relationship between students' attitudes and learning styles and students' motivations towards physics subject. It can be concluded that attitude indicators, namely is an inquiry attitude indicators in physics have good criteria, attitude adoption indicators scientific has sufficient criteria and for indicators of interest in increasing the time to study has good criteria. Whereas the dominant learning style in the four schools studied was a visual learning style with a percentage of mastery of $46.7 \%$. For students, learning motivation also has a high percentage of $41.4 \%$. There is a relationship between learning styles and attitudes towards physics subjects at the significance of 0.44 and also there is a relationship between motivation and attitudes of students in the four schools studied.
\end{abstract}

Keywords Assessment, Attitude, Learning Style, Motivation, Physics Subject

\section{Introduction}

Attitude is a person's feelings that arise towards an object, and occur naturally $[1,2]$. In the approach of attitudes and views of students towards science learning, things that must be understood are the meaning of attitudes, the development of attitudes, and their impact on the learning process, and student decision making towards science in the future [3]. A person's response to certain objects of thought and behavior is called attitude.

Attitude is considered important in a learning process [4, 5]. How to teach teachers to study not stiff cause students liked the lessons. This is because effective assessment (attitudes) on human rights defenders is very important to know the attitudes of students towards a subject so that later it can help teachers determine the right learning strategies for students, which later can be used as a reference to increase interest in a subject $[6,7]$. That to increase the use of appropriate teaching or training strategies, students' problem solving attitudes and abilities can be used [8]. The criteria for student attitudes that will be seen in this study use an attitude assessment instrument, whose indicators refer to the attitude assessment instrument of TOSRA (Test of Related Scientific Attitudes) by [9]. The attitude indicators that must be seen in this study are attitudes towards investigations in physics, adoption of scientific attitudes, and interest in multiplying the time to study physics, so that it refers to student attitudes towards the subject of physics.

Physics is one of the subjects which discusses real phenomena and symptoms. Where, or the famous physics lesson is the most elusive and frightening for students. Students assume that physics is difficult, because they tend to memorize formulas and abstract physics concepts [10]. In this case, students must be able to learn how to absorb and process information in learning, because students have no difficulty in learning [11]. This can be determined by the learning style of each individual student. Every student must have a different learning style. Thus, since students have very different learning styles, it is the instructor's responsibility to overcome the diversity of learning styles among students and develop an appropriate learning defense approaches [12]. Learning styles are cognitive, affective, and physiological behavioral characteristics that serve as relatively stable indicators of how students understand, interact with, and respond to the learning environment [13].

Learning styles can be very helpful and useful for students who will focus more on attentive learning, which in turn will increase educational success [14]. So that it can support school learning goals. Learning styles have several indicators, 
namely visual learning styles, auditory learning styles and kinesthetic learning styles. Paying attention to a variety of student learning styles can increase student learning motivation. In particular, student motivation and performance increases when teaching is tailored to information and student learning styles [15].

In general, motivation means something that is encouraging for do or in action. Motivation could interpreted as strength (energy) of a person who can raises level persistence and enthusiastic in doing an activity, both sourced from self-individual that alone (motivation intrinsic) [16]. For example, students have will own for learn physics, capable and concentrating at the moment learn physics. As well from outside of individual (motivation) extrinsic), like get gift and get good value [17].

1. What is the description attitude towards inquiry in physics?

2. What is the description adoption of scientific attitudes?

3. What is the description interest in multiplying when studying physics?

4. What is the description of student learning styles?

5. What is the description of student motivation?

6. Is there relationship between attitude and student learning style?

7. Is there a relationship between attitude and student motivation?

\section{Materials and Methods}

Quantitative research methods with a correlational research design. According to [18] Correlational Design is a procedure in quantitative research that is used by researchers to measure the degree of association (relationship) between two or more variables using statistical analysis correlation procedures. The study sample was 623 students. Samples are designed and determined by sampling techniques in the form of total sampling. Total sampling is a technique of determining samples that uses all populations as a sample [18]. The research sample was carried out throughout the science class. Learning styles were measured using a questionnaire with a number of 28 items. Then motivation is measured using the questionnaire with the number 23 . This type of questionnaire is an open questionnaire. Then the learning style also uses interviews. Furthermore, the attitude uses 54 questionnaires. The type of questionnaire is an open questionnaire. Attitudes also use interviews. Learning style questionnaire criteria are visual learning style, auditory learning style and kinesthetic learning style. For the criteria for attitude questionnaire, namely the adoption of scientific attitudes, pleasure in learning physics, interest in increasing the time to study physics and a career in physics, and motivation to learn physics. Data analysis uses descriptive and inferential statistics. To obtain descriptive statistics mean, median, mode, standard deviation, minimum and maximum. Descriptive statistics are part of statistics that learn how to collect and present data so that it is easy to understand $[19,20]$. Statistical inference from mathematical procedures for using probabilities and information about samples to draw conclusion about the population from which the sample is presumably was drawn [21].

\section{Results}

Students can be viewed from the characteristics of students, namely from feeling happy, or just ordinary from these students. That student can be seen from feeling happy, unhappy, like or dislike, motivated or unmotivated. Attitude is a term that reflects pleasure, displeasure or an ordinary feeling (neutral) of a person towards something [22]. We define attitude as an internal state that influences (moderates) the choices of personal actin made by the individual [23]. Attitudes are generally considered to have affective (emotional) components, cognitive aspects, and behavioral consequences. The effects could in terms of attitude, interest, motivation, selfconfidence or self concept toward the subjects that they have in school, even toward the school environment, like their teachers or the friends of theirs [24]. Students who have a visual learning style like to be given demonstrations and learn through descriptions, like to use lists to maintain speed and regulate thoughts, remember faces but often forget names, and are disturbed by movements or actions but noise is usually not disturbing [25]. Students really like learning with lab work or demonstrations. Found that most students preferred kinesthetic style [26]. The students who have a negative attitude towards physics have a lack of motivation for class engagement, and also the students who have positive attitudes towards physics have motivation for class engagement [27].

The validity of this research is viewed from the indicators of social implication of physics, the normality of scientists and interest in career in physics derived from [9] research and implemented in Indonesia in terms of validity and reliability with validity values of 54 statements and having Cronbach alpha values of 0.9 carried out by [28]. What will be examined in this study are 3 indicators, namely social implication of physics, Normality of Scientists, and Interest in a career in physics.

Based on this study on the relationship of student attitudes toward physics with learning styles and motivation with the following results:

\subsection{Attitude towards Inquiry in Physics}

For the results of attitude toward inquiry in physics of students in high school 5 and 10 muaro jambi can be seen below: 
Table 1. Attitudes towards inquiry in physics in high school 5 and 10 muaro jambi and high school 5 and 10Jambi cities

\begin{tabular}{|c|c|c|c|c|c|c|c|c|c|c|c|c|c|c|}
\hline \multicolumn{11}{|c|}{ Category } & & \multirow{3}{*}{ Mean } & \multirow{3}{*}{ Min } & \multirow{3}{*}{ Max } \\
\hline \multirow[t]{2}{*}{ Interval } & \multicolumn{2}{|c|}{$\begin{array}{c}\text { MJ } 5 \\
\text { High } \\
\text { School }\end{array}$} & \multicolumn{2}{|c|}{$\begin{array}{l}\text { MJ } 10 \\
\text { High } \\
\text { School }\end{array}$} & \multicolumn{2}{|c|}{$\begin{array}{l}\text { BT } 5 \\
\text { SMA }\end{array}$} & \multicolumn{2}{|c|}{$\begin{array}{l}\text { BT } 10 \\
\text { SMA }\end{array}$} & \multirow[t]{2}{*}{ Attitude } & \multirow[t]{2}{*}{ Total } & \multirow[t]{2}{*}{$\%$} & & & \\
\hline & $\mathrm{F}$ & M & $\mathrm{F}$ & M & $\mathrm{F}$ & M & $\mathrm{F}$ & M & & & & & & \\
\hline $9.0-16.2$ & 6 & 2 & 5 & 3 & 5 & 0 & 0 & 0 & Very Not Good & 21 & 3.4 & \multirow{5}{*}{36.5} & \multirow{5}{*}{14} & \multirow{5}{*}{44} \\
\hline $16.3-23.4$ & 8 & 4 & 9 & 4 & 7 & 6 & 9 & 8 & Not good & 55 & 8.8 & & & \\
\hline $23.5-30.6$ & 21 & 12 & 35 & 28 & 19 & 34 & 29 & 34 & Enough & 212 & 34.0 & & & \\
\hline $30.7-37.8$ & 47 & 42 & 34 & 21 & 52 & 29 & 32 & 21 & Good & 278 & 44.6 & & & \\
\hline $37.9-45.0$ & 14 & 8 & 3 & 5 & 4 & 2 & 14 & 7 & Very Good & 57 & 9.2 & & & \\
\hline \multirow{2}{*}{ TOTAL } & 96 & 68 & 86 & 61 & 87 & 71 & 84 & 70 & & \multirow{2}{*}{623} & \multirow{2}{*}{100} & & & \\
\hline & \multicolumn{2}{|c|}{164} & \multicolumn{2}{|c|}{147} & \multicolumn{2}{|c|}{158} & \multicolumn{2}{|c|}{154} & & & & & & \\
\hline
\end{tabular}

* MJ = Muaro Jambi; BT = Jambi City; F = Female; $\mathrm{M}=$ Male

From table 1 came from 623 respondents from Muaro Jambi high school and Jambi city students, for male students in high school 5 muaro jambi good category with 42 in high school 10 muaro jambi with a sufficient number of 28, high school 5 jambi city categorized enough by the number of 34 students and high schools 10 jambi cities have enough categories totaling 34 students. Then for female in high school 5 muaro jambi in good category as many as 42 students, middle to upper 10 muaro jambi quite a number of 35, high school 5 jambi city good category with a total of 52 students and high school 10 jambi city has a good category with 32 students. Processed results using the SPSS program application, it was obtained for attitude towards investigation in physics to have a good category of $44.6 \%$ for a total of 278 of 623 students, and Vey Not Good at 3.4\% for a total of 21 out of 623 students. For 623 students, the Mean 36.5, Maximum Value 44, and Minimum Value 14.

\subsection{Adoption of Scientific Attitudes}

For the results of the adoption of scientific attitudes of students in high school 5 and 10 muaro jambi can be seen below:

Table 2. Adoption of scientific attitudes in high schools 5 and 10 muaro jambi and high schools 5 and 10 of Jambi city

\begin{tabular}{|c|c|c|c|c|c|c|c|c|c|c|c|c|c|c|}
\hline \multicolumn{11}{|c|}{ Category } & & \multirow{3}{*}{ Mean } & \multirow{3}{*}{ Min } & \multirow{3}{*}{ Max } \\
\hline \multirow[t]{2}{*}{ Interval } & \multicolumn{2}{|c|}{$\begin{array}{c}\text { MJ } 5 \\
\text { High } \\
\text { School } \\
\end{array}$} & \multicolumn{2}{|c|}{$\begin{array}{c}\text { MJ } 10 \\
\text { High } \\
\text { School } \\
\end{array}$} & \multicolumn{2}{|c|}{$\begin{array}{l}\text { BT } 5 \\
\text { SMA }\end{array}$} & \multicolumn{2}{|c|}{$\begin{array}{l}\text { BT } 10 \\
\text { SMA }\end{array}$} & \multirow[t]{2}{*}{ Attitude } & \multirow[t]{2}{*}{ Total } & \multirow[t]{2}{*}{$\%$} & & & \\
\hline & $\mathrm{F}$ & M & $\mathrm{F}$ & M & $\mathrm{F}$ & M & $\mathrm{F}$ & M & & & & & & \\
\hline $7.0-12.6$ & 6 & 2 & 3 & 0 & 1 & 0 & 0 & 1 & Very Not Good & 13 & 2.1 & \multirow{5}{*}{22.3} & \multirow{5}{*}{11} & \multirow{5}{*}{33} \\
\hline $12.7-18.2$ & 9 & 4 & 7 & 4 & 4 & 13 & 9 & 8 & Not good & 58 & 9.3 & & & \\
\hline $18.3-23.8$ & 41 & 32 & 29 & 31 & 43 & 26 & 33 & 29 & Enough & 264 & 42.2 & & & \\
\hline $23.9-29.4$ & 27 & 22 & 42 & 21 & 32 & 24 & 28 & 24 & Good & 220 & 35.3 & & & \\
\hline $29.5-35.0$ & 13 & 8 & 5 & 5 & 7 & 8 & 14 & 8 & Very Good & 68 & 10.9 & & & \\
\hline \multirow{2}{*}{ TOTAL } & 96 & 68 & 86 & 61 & 87 & 71 & 84 & 70 & & \multirow{2}{*}{623} & \multirow{2}{*}{100} & & & \\
\hline & \multicolumn{2}{|c|}{164} & \multicolumn{2}{|c|}{147} & \multicolumn{2}{|c|}{158} & \multicolumn{2}{|c|}{154} & & & & & & \\
\hline
\end{tabular}

* MJ = Muaro Jambi; BT = Jambi City; F = Female; $\mathrm{M}=$ Male

From table 2, which came from 623 respondents from Muaro Jambi high school and Jambi city, for male students in senior high school 5 muaro jambi enough with the number 32, in senior high school 10 muaro jambi quite enough with the number 31, high school 5 jambi city categorized enough by the number of 26 students and high schools 10 jambi cities have enough categories totaling 29 students. Then for female in high school 5 muaro jambi enough as many as 41 students, high school 10 muaro jambi good category amounting to 42, high school 5 jambi city categorized enough with a total of 43 students and high school 10 jambi city has enough categories with 33 students. Processed results using the SPSS program application, it was obtained for adoption of the attitude of physics have a enough category $42.2 \%$ for a total of 264 students, and Vey Not Good at $2.1 \%$ for a total of 13 out of 623 students. For 623 students, the Mean 22.3, Maximum Value 33, and Minimum Value 11. 


\subsection{Adoption of Scientific Attitudes}

For the results of the interest increase time to learn physics of students in high school 5 and 10 muaro jambi can be seen below

Table 3. Interest in increasing the time to study physics in high school 5 and 10 muaro jambi and high school 5 and 10 Jambi city

\begin{tabular}{|c|c|c|c|c|c|c|c|c|c|c|c|c|c|c|}
\hline \multicolumn{11}{|c|}{ Category } & & \multirow{3}{*}{ Mean } & \multirow{3}{*}{ Min } & \multirow{3}{*}{ Max } \\
\hline \multirow[t]{2}{*}{ Interval } & \multicolumn{2}{|c|}{$\begin{array}{c}\text { MJ } 5 \\
\text { High } \\
\text { School }\end{array}$} & \multicolumn{2}{|c|}{$\begin{array}{c}\text { MJ } 10 \\
\text { High } \\
\text { School }\end{array}$} & \multicolumn{2}{|c|}{$\begin{array}{l}\text { BT } 5 \\
\text { SMA }\end{array}$} & \multicolumn{2}{|c|}{$\begin{array}{l}\text { BT } 10 \\
\text { SMA }\end{array}$} & \multirow[t]{2}{*}{ Attitude } & \multirow[t]{2}{*}{ Total } & \multirow[t]{2}{*}{$\%$} & & & \\
\hline & $\mathrm{F}$ & M & $\mathrm{F}$ & $\mathrm{M}$ & $\mathrm{F}$ & M & $\mathrm{F}$ & M & & & & & & \\
\hline $8.0-14.4$ & 0 & 3 & 0 & 2 & 6 & 0 & 4 & 1 & Very Not Good & 16 & 2.6 & \multirow{5}{*}{31.5} & \multirow{5}{*}{12} & \multirow{5}{*}{38} \\
\hline $14.5-20.8$ & 8 & 5 & 7 & 4 & 9 & 6 & 7 & 4 & Not good & 50 & 8.0 & & & \\
\hline $20.9-27.2$ & 32 & 22 & 35 & 27 & 34 & 34 & 26 & 26 & Enough & 236 & 37.9 & & & \\
\hline $27.3-33.6$ & 39 & 32 & 31 & 23 & 35 & 29 & 37 & 30 & Good & 256 & 41.1 & & & \\
\hline $33.7-40.0$ & 17 & 6 & 12 & 5 & 2 & 2 & 13 & 9 & Very Good & 66 & 10.4 & & & \\
\hline \multirow{2}{*}{ TOTAL } & 96 & 68 & 86 & 61 & 87 & 71 & 84 & 70 & & \multirow{2}{*}{623} & \multirow{2}{*}{100} & & & \\
\hline & \multicolumn{2}{|c|}{164} & \multicolumn{2}{|c|}{147} & \multicolumn{2}{|c|}{158} & \multicolumn{2}{|c|}{154} & & & & & & \\
\hline
\end{tabular}

* MJ = Muaro Jambi; BT = Jambi City; F = Female; $\mathrm{M}=$ Male

From table 3, it came from 623 respondents from Muaro Jambi high school and Jambi city, for male students in high school 5 muaro jambi in good category with 32 in high school 10 muaro jambi in sufficient category with 27, high school 5 jambi city categorized enough with 34 students and high school 10 jambi city has a good category of 30 students. Then for female in high school 5 muaro jambi good category as many as 39 students, middle to upper 10 muaro jambi quite a number of 35, high school 5 jambi city good category with 35 students and high school 10 jambi city has a good category with 37 students. SPSS program application, it was obtained for interest in increasing physics learning time to have a good category of $41.1 \%$ for a total of 256 of 623 students, and Vey Not Good at $2.6 \%$ for a total of 16 out of 623 students. For 623 students, the Mean 31 .5, Maximum Value 38, and the Minimum Value 12.

\subsection{Student's Motivation to Study}

For the results of the students motivation of students in high school 5 and 10 muaro jambi can be seen below:

Table 4. Motivation Student learning in high school 5 and 10 muaro jambi and high school 5 and 10 Jambi city

\begin{tabular}{|c|c|c|c|c|c|c|c|c|c|c|c|c|c|c|}
\hline \multicolumn{11}{|c|}{ Category } & & \multirow{3}{*}{ Mean } & \multirow{3}{*}{ Min } & \multirow{3}{*}{$\operatorname{Max}$} \\
\hline \multirow[t]{2}{*}{ Interval } & \multicolumn{2}{|c|}{$\begin{array}{c}\text { MJ } 5 \\
\text { High } \\
\text { School }\end{array}$} & \multicolumn{2}{|c|}{$\begin{array}{l}\text { MJ } 10 \\
\text { High } \\
\text { School }\end{array}$} & \multicolumn{2}{|c|}{$\begin{array}{l}\text { BT } 5 \\
\text { SMA }\end{array}$} & \multicolumn{2}{|c|}{$\begin{array}{l}\text { BT } 10 \\
\text { SMA }\end{array}$} & \multirow[t]{2}{*}{ Attitude } & \multirow[t]{2}{*}{ Total } & \multirow[t]{2}{*}{$\%$} & & & \\
\hline & $\mathrm{F}$ & $\mathrm{M}$ & $\mathrm{F}$ & $\mathrm{M}$ & $\mathrm{F}$ & M & F & M & & & & & & \\
\hline $23.0-41.4$ & 3 & 2 & 0 & 1 & 5 & 0 & 3 & 4 & Very Not Good & 18 & 2.9 & \multirow{5}{*}{93.7} & \multirow{5}{*}{31} & \multirow{5}{*}{112} \\
\hline $41.5-59.8$ & 8 & 4 & 7 & 9 & 7 & 4 & 9 & 8 & Not good & 56 & 8.9 & & & \\
\hline $59.9-78.2$ & 26 & 26 & 35 & 23 & 23 & 30 & 21 & 29 & Enough & 213 & 34.3 & & & \\
\hline $78.3-96.6$ & 43 & 29 & 31 & 19 & 42 & 34 & 39 & 21 & Good & 258 & 41.4 & & & \\
\hline $96.7-115$ & 16 & 7 & 13 & 9 & 10 & 3 & 12 & 8 & Very Good & 78 & 12.5 & & & \\
\hline \multirow{2}{*}{ TOTAL } & 96 & 68 & 86 & 61 & 87 & 71 & 84 & 70 & & \multirow{2}{*}{623} & \multirow{2}{*}{100} & & & \\
\hline & \multicolumn{2}{|c|}{164} & \multicolumn{2}{|c|}{147} & \multicolumn{2}{|c|}{158} & \multicolumn{2}{|c|}{154} & & & & & & \\
\hline
\end{tabular}

* MJ = Muaro Jambi; BT = Jambi City; F = Female; M = Male

From table 4, it came from 623 respondents from Muaro Jambi high school and Jambi city, for male students in high school 5 muaro jambi well categorized with the number 29, in senior high school 10 muaro jambi quite enough with the number 23, high school 5 the city of Jambi is well categorized with a total of 34 students and high school 10 cities of Jambi having a sufficient number of 29 students. Then for female in high school 5 muaro jambi good categories as many as 43 students, middle to upper 10 muaro jambi categorized enough number 35, high school 5 jambi city good category with 42 students and high school 10 jambi city has a good category with total of 39 students. Processed results using the SPSS program application, it was obtained for student motivation in learning physics to have a good category of $41.4 \%$ for a total of 258 of 623 students, and Vey Not Good at $2.9 \%$ for a total of 18 out of 623 students. For 623 students, the Mean 93.7, Maximum V is 112, and Minimum Value 31. 


\subsection{Student Learning Style}

For the results of the students learning style of students in high school 5 and 10 muaro jambi can be seen below:

Table 5. Student Learning Styles in high schools 5 and 10 muaro jambi and high school 5 and 10 Jambi city

\begin{tabular}{|c|c|c|c|c|c|c|c|c|c|c|c|c|c|}
\hline \multicolumn{11}{|c|}{ Category } & \multirow{3}{*}{ Mean } & \multirow{3}{*}{ Min } & \multirow{3}{*}{ Max } \\
\hline \multirow[t]{2}{*}{ Indicator } & \multicolumn{2}{|c|}{ SMA $5 \mathrm{MJ}^{*}$} & \multicolumn{2}{|c|}{$\begin{array}{l}10 \text { MJ High } \\
\text { School* }\end{array}$} & \multicolumn{2}{|c|}{ BT 5 SMA* } & \multicolumn{2}{|c|}{$\begin{array}{c}\text { BT } 10 \text { High } \\
\text { School* }\end{array}$} & \multirow[t]{2}{*}{ Total } & \multirow[t]{2}{*}{$\%$} & & & \\
\hline & $\mathrm{F}$ & $\mathrm{M}$ & $\mathrm{F}$ & $\mathrm{M}$ & $\mathrm{F}$ & $\mathrm{M}$ & $\mathrm{F}$ & $\mathrm{M}$ & & & & & \\
\hline Vicul & & 31 & 20 & (1) & 20 & 28 & 25 & 20 & 201 & 467 & \multirow{3}{*}{43.0} & \multirow{3}{*}{5} & \multirow{3}{*}{27} \\
\hline Auitorial & 24 & 27 & 41 & 8 & 23 & 19 & 25 & 18 & 185 & 29.7 & & & \\
\hline Kinesthetic & 15 & 10 & 6 & 11 & 34 & 24 & 24 & 23 & 147 & 23.6 & & & \\
\hline \multirow{2}{*}{ TOTAL } & 96 & 68 & 86 & 61 & 87 & 71 & 84 & 70 & \multirow{2}{*}{623} & \multirow{2}{*}{100} & & & \\
\hline & \multicolumn{2}{|c|}{164} & \multicolumn{2}{|c|}{147} & \multicolumn{2}{|c|}{158} & \multicolumn{2}{|c|}{154} & & & & & \\
\hline
\end{tabular}

* MJ = Muaro Jambi; BT = Jambi City; F = Female; $\mathrm{M}=$ Male

From table 5 which came from 623 respondents from Muaro Jambi high school and Jambi city, for male students in high school 5 muaro jambi the dominant was visual with the number 31, in high school 10 the dominant muaro jambi was visual with a total of 42, the high school 5 of the dominant city of Jambi is visual with a total of 28 students and 10 high schools in the city of Jambi having a dominant visual with 29 students. Then for female in senior high school 5 muaro dominant in visual as many as 57 students, middle to upper 10 muaro jambi dominant in auditor numbering 41 , high school 5 jambi city predominantly anesthetized with 34 students and 10 high schools in Jambi city the dominant one is visual with 35 students. Using the SPSS program application, it was obtained for Learning Style Students to have a visual of $46.7 \%$ for a total of 291 of 623 , Auditorial of $29.7 \%$ for a total of 185 of 623 students, kinesthetic at $23.6 \%$ for a total of 147 out of 623 students, and have a Mean 43.0, Maximum Value 27 , and Minimum Value 5.

\subsection{Relationship between Attitudes and Motivation Students in High School 5 and 10 Muaro Jambi and High Schools 5 and 10 Jambi City}

For the results of the relationship between attitudes and learning styles of students in high school 5 and 10 muaro jambi can be seen below:

Table 6. Relationship between Attitudes and Motivation Students in high school 5 and 10 muaro jambi and high school 5 and 10 Jambi cities

\begin{tabular}{|c|c|c|c|c|c|c|c|c|c|}
\hline & & M_5MJ & A_5MJ & M_10MJ & A_10MJ & M_5BT & A_5BT & M_10BT & A_10BT \\
\hline \multirow{3}{*}{ Motivation_School } & $\begin{array}{c}\text { Pearson } \\
\text { Correlation }\end{array}$ & 1 & $.538^{* *}$ & 1 & $.732^{* *}$ & 1 & $.796^{* *}$ & 1 & $.683^{* *}$ \\
\hline & Sig.(2-tailed) & & .28 & & .066 & & .001 & & .11 \\
\hline & $\mathrm{N}$ & 164 & 164 & 147 & 147 & 158 & 158 & 154 & 154 \\
\hline \multirow{3}{*}{ Attitude_School } & $\begin{array}{c}\text { Pearson } \\
\text { Correlation }\end{array}$ & $.538^{* *}$ & 1 & $.732^{* *}$ & 1 & $.796^{* *}$ & 1 & $.683^{* *}$ & 1 \\
\hline & Sig.(2-tailed) & .28 & & .006 & & .001 & & .011 & \\
\hline & $\mathrm{N}$ & 164 & 164 & 147 & 147 & 158 & 158 & 154 & 154 \\
\hline
\end{tabular}

* $\mathrm{M}=$ Motivation; $\mathrm{A}=$ Attitude; $\mathrm{MJ}=$ Muaro Jambi; $\mathrm{BT}=$ Jambi City

From the table 6 we can see for high school 5 Muaro Jambi the sig value is 0.028 small from 0.05 , it can be concluded that there is a relationship between motivations. If the value of sig $<0.05$, then there is a relationship [21]. It can be seen untu k secondary school on 10 Muaro that the sig value is 0.006 small than 0.05 , so we can conclude that there is a relationship between motivation. If the value of $\operatorname{sig}<0.05$, then there is a relationship [21]. It can be seen for high school 5 in Jambi City the sig value is 0.000 small from 0.05 , and we can conclude that there is a relationship between motivation. If the value of sig $<0.05$, then there is a relationship [21]. It can be seen for high school 10 Jambi city the value is 0.011 small from 0.05 , and we can conclude that there is a relationship between motivation. If the value of sig $<0.05$ then there is a relationship [21].

\subsection{Relationship between Attitudes and Student Learning Styles in high schools 5 and 10 muaro jambi and high schools 5 and 10Jambi city}

For the results of the relationship between attitudes and learning styles of students in high school 5 and 10 muaro jambi can be see below: 
Table 7. Relationship between Students' Attitudes and Learning Styles in high school 5 and 10 muaro jambi and high school 5 and 10 Jambi city

\begin{tabular}{|c|c|c|c|c|c|c|c|c|c|}
\hline \multicolumn{2}{|c}{} & LS_5MJ & A_5MJ & LS_10mJ & A_10MJ & LS_5BT & A_5BT & LS_10BT & A_10BT \\
\hline \multirow{4}{*}{$\begin{array}{c}\text { Learning } \\
\text { Style_School }\end{array}$} & $\begin{array}{c}\text { Pearson } \\
\text { Correlation }\end{array}$ & 1 & $.618^{* *}$ & 1 & $.632^{* *}$ & 1 & $.846^{* *}$ & 1 & $.853^{* *}$ \\
\cline { 2 - 10 } & Sig.(2-tailed) & & .16 & & .008 & & .031 & .001 \\
\cline { 2 - 11 } & $\mathrm{N}$ & 164 & 164 & 147 & 147 & 158 & 158 & 154 & 154 \\
\hline \multirow{4}{*}{ Attitude_School } & $\begin{array}{c}\text { Pearson } \\
\text { Correlation }\end{array}$ & $.618^{* *}$ & 1 & $.632^{* *}$ & 1 & $.846^{* *}$ & 1 & $.853^{* *}$ & 1 \\
\cline { 2 - 11 } & Sig.(2-tailed) & .16 & & .008 & & .031 & & .000 & 154 \\
\cline { 2 - 11 } & $\mathrm{N}$ & 164 & 164 & 147 & 147 & 158 & 158 & 154 \\
\hline
\end{tabular}

* LS = Learning Style; A = Attitude; MJ = Muaro Jambi; BT = Jambi City

From table 7, we can see for high school 5 Muaro Jambi the sig value is 0.16 small from 0.05 . It can be concluded that there is a relationship between learning study. If the value of sig $<0.05$, then there is a relationship [21]. It can be seen for high school 10 Muaro Jambi that the value is 0.008 smaller than 0.05 , so we can conclude that there is a relationship between learning studies. If the value of sig $<0.05$, then there is a relationship [21]. It can be seen for high school 5 in Jambi City, the value is 0.031 small from 0.05 , and we can conclude that there is a relationship between learning studies. If the value of sig $<0.05$, then there is a relationship [21]. It can be seen for high school 10 Jambi City the sig value is 0.000 small from 0.05 , and we can conclude that there is a relationship between learning studies. If the value of sig $<0.05$, then there is a relationship [21].

\section{Results}

Students can be viewed from the characteristics of students, namely from feeling happy, or just from the students. Students' attitudes can be seen from feeling happy, happy, like or dislike, motivated or unmotivated. Then students can determine the appropriate learning styles. The arrogance of this study was viewed from the indicators of the attitude of inquiry towards learning physics, the adoption of scientific attitudes, the interest in increasing the time of physics learning which came from [9] research and implemented in Indonesia in terms of validity and reliability with a value of 54 approvals and values Cronbach alpha is 0.9 done by [28]. What will continue in this study are 3 indicators, namely the social implications of physics, the Normality of Scientists, and Interest in a career in physics

\subsection{The Attitude of Investigation towards Learning Physics}

The attitude of investigation towards learning physics is in a good category with $44.6 \%$. The results of interview attitudes toward learning physics in a good category indicate that they prefer to learn by experimenting or experimenting, because while learning and easy to understand. They also choose to ask experts or friends, who know more about problems and problems about physics. Students, who get good criteria scores are shown by liking learning through experimentation, but experimental or experimental learning, must use expensive learning tools and media. Experimental methods require various facilities, such as lat and materials that are always not easily available and expensive [29]. Students who get good criteria say that they prefer experimental learning rather than asking questions or studying directly with the teacher. Learning using experiments, although not boring, is also easier to understand and understand [30]. This attitude has been possessed by almost all students that in its application can improve student collaboration in learning. Experimental learning also trains collaboration between students [31]. Students must put aside selfishness. The experimental method can make students remember longer, by getting a direct learning experience so as to make learning more meaningful. Applying experimental methods in teaching and learning activities can make physics learning more meaningful because students experience and prove themselves something that is learned [32]. A learning environment that is in accordance with learning needs will help in achieving learning goals. The learning environment must be designed in such a way as to enable students to achieve scientific knowledge and gain a more positive attitude towards science [33].

\subsection{Adoption of Scientific Attitudes}

Adoption of scientific attitudes obtained results are in the good category of $42.2 \%$. K then results the interviews found that those who scored without criteria were good enough to hear other people's opinions that were different from their minds, and they also revealed that they like to use new methods that have never been used for experiments. Students whose scores are well enough argue that they like to listen to the opinions of others, and like to use new methods in experiments. Students must be able to apply well the various methods that will be used in scientific learning. A student must have the ability to adapt to overcome change by regulating his scientific attitude for 
himself and learning to solve problems from an early age [6]. Students who score with good criteria reveal that they like to hear new ideas or thoughts from others, and some like to use new methods in experiments. Having applied scientific attitude in the learning process, the scientific attitude shown by students is one form of change in learning outcomes. One's scientific attitude can develop with interaction with friends who are more proficient because there will be mutual respect for each other [34]. Students, who value scientific research and have confidence in their ability to be involved in the process of scientific education, are able to complete scientific tasks efficiently and overcome difficulties in solving scientific problems [35].

\subsection{Interest Increases when Studying Physics}

Attitudes towards interest in increasing physics learning time obtained from the results of research, good criteria got $41.1 \%$. Whereas the results of the interview show that those who score with good criteria say that they like to read news or articles about physics and sometimes talk about physics with friends at home from school. Students who score with good criteria state that they want to take part in physics learning activities, but not in school activities related to physics challenges. Students who score poorly on criteria reveal that they are not interested in increasing their physics study time by attending physics tutoring or extracurricular activities, and do not like to read physics books during the holidays. Students who like certain fields will tend to be consistent about learning material, such as doing homeschool work, taking more time to study material with different activities. [36], when studying the materials continuously and consistently attempt to do homework, to look for opportunities to learn more, to do additional work, etc. [17], if a student has a negative attitude towards the subject of physics, then he will tend to be less motivated in class involvement and dislike teachers and physics courses. Students who like a particular object or have a positive attitude towards a particular object are shown by the tendency to approach, like, and expect certain objects [37]. Conversely, if students who do not like or have a negative attitude towards certain objects will be shown by the attitude of avoiding, avoiding, hating and disliking certain objects.

\subsection{Motivation}

Based on above results dikat eg orikan good motivation for $41.4 \%$. Students are very motivated to learn physics. According to [16] in general, motivation means something that encourages to do or act. For example, students should have their own willingness to learn physics, be able and concentrate while studying physics [16]. Student learning outcomes will be optimal if students are motivated in learning. Motivation in learning can influence how the process and learning outcomes of a student. According to [39] motivated behavior is a behavior that is full of energy, directed, and enduring. Furthermore, learning media can produce motivation, learning stimuli, and bring psychological influence to students, so students become more aware of the material being studied.

\subsection{Learning Style}

Based on the results above the learning style is categorized as good, the visual indicator is $46.7 \%$. Learning styles can be defined as individual businesses to achieve their learning goals. Finding this learning style will enable students to determine the strengths and weaknesses of their own personalities and learn from them [14]. Students can recognize learning styles that are in accordance with individual characteristics. It does force us to do it by making different class concepts by focusing on the various ways students learn [12]. According to [40], learning styles can be classified into three types of styles, namely visual, auditory and kinesthetic. Learning styles that are often applied by students are visual learning styles because students prefer to read while studying, are not disturbed by noise, like to look good in clothes, and are skilled in learning [41]. Positive things obtained from the visual learning style of students are more likely to be active in learning. A student who likes visual perception will be very comfortable with instructors who use graphics, pictures, and films [42]. The findings are that students prefer to learn by seeing, reading physics books, being active in answering questions in front of the class and while learning always sit neatly. They depend on non-verbal cues from the instructor or facilitator such as body language to help understand learning [14]. Usually students and visuals like to sit in front of the class while studying

\subsection{Relationship between Attitudes and Motivation Students in High School 5 and 10 Muaro Jambi and High School 5 and 10Jambi City}

Based on the result of the relationship attitudes and motivation of students in secondary schools on 5 Muaro jambi sig result of correlation of 0.028 high schools 10 muaro jambi for sig 0.006 , which means that there is a relationship between attitude and student motivation because if sig $<0.05$ then there is a relationship. Then the results of the relationship of attitudes and motivation of students in high school 5 Jambi city sig result is 0.001 . and senior high school 10 Jambi City by 0.011 , which means that there is a relationship between attitude and student motivation because if sig $<0.05$ then there is a relationship. If students have a good attitude towards physics subjects, students will be motivated to learn. From the statements of [16], we can conclude that motivation is very important towards attitudes, so that motivation and attitudes are interconnected. 


\subsection{Relationship between Attitudes and Student Learning Styles in High Schools 5 and 10 Muaro Jambi and High Schools 5 and 10Jambi City}

Based on the result of the relationship attitudes and learning styles of students in secondary schools on 5 Muaro jambi sig results of correlation of 0.016 , high schools 10 muaro jambi for sig 0.008 . Which means there is a relationship between attitude and learning styles of students because if sig $<0.05$ then there is a relationship. Then the results of the relationship between students' attitudes and learning styles in high school 5 Jambi city sig result is 0.031 and high school 10 Jambi city of 0.001 . Which means there is a relationship between attitude and learning styles of students because if sig $<0.05$ then there is a relationship. The relationship between attitudes and learning styles states that appropriate learning styles by individuals will enhance positive attitudes towards physics subjects. If students have a good and appropriate learning style will positively impact students' attitudes towards their subjects, where learning styles are a characteristic of cognitive, affective and psychomotor, as indicators that act relatively stable for learning that are interconnected and react to the learning environment [43]. Because of these different learning styles, it is important for teachers to join their curriculum activities related to each of these learning styles so that all students can succeed in their classrooms [12].

\section{Conclusions}

Based on research conducted at Muaro Jambi High School 5, Muaro Jambi High School 10, Jambi City High School 5 and Jambi City High School 10, it can be concluded that attitude indicators, namely inquiry attitude indicators in physics have good criteria, attitude adoption indicators scientific has sufficient criteria and for indicators of interest in increasing the time to study has good criteria. Whereas the dominant learning style in the four schools studied was a visual learning style with a percentage of mastery of $46.7 \%$. For student learning motivation also has a high percentage of $41.4 \%$. There is a relationship between learning styles and attitudes towards physics subjects at the significance of 0.44 and also there is a relationship between motivation and attitudes of students in the four schools studied.

\section{Acknowledgements}

The researcher would like to thank the headmaster of senior high school $5 \& 10$ Muaro Jambi, and the head of senior high school $5 \& 10$ Jambi City, the teachers and of course the students who have been willing to be sampled in this study, I thank you, and all parties involved I say thank you for it.

\section{REFERENCES}

[1] Astalini, Kurniawan, D. A., Darmaji., Sitorus, L. R., Perdana, R. Characteristic Of Students Attitude To Physics In Muaro Jambi High School. Humanities \& Social Science Reviews. 7(2), 91-99. 2019. https://doi.org/1018510/hssr.2019.7210

[2] Kind, P., Jones, K., \& Barmby, P. (2007). Developing Attitudes towards Science Measures. International Journal of Science Education, 29 (7), 871-893.

[3] Raved, L., \& Assaraf, OBZ (2011). Attitudes towards Science Learning Among 10th - Grade Students: A Qualitative Look. International Journal Of Science Education, 33 (9), 1219-1243.

[4] Astalini, Kurniawan, D. A., Perdana, R., \& Kurniasari, D. (2018). Identification of Student Attitudes toward Physics Learning At Batanghari District High School. The Educational Review, Usa, 2(9), 475-484.

[5] Darmaji., Kurniawan, D. A., Parasdila, H., \& Irdianti. (2018). Description of Science Process Skills' Physics Education Students at Jambi University in Temperature and Heat Materials. The Educational Review, USA. 2(9): 485-498.

[6] Astalini, Kurniawan, D. A., Perdana, R., \& Kurniawan, W. (2019). Identification Attitudes of Learners on Physics Subjects. EST Journal of Educational Science and Technology, 5(1), 39-48. DOI: https://doi.org/10.26858/est.v5i1.8231

[7] Astalini, Kurniawan, D. A., Perdana, R., \& Pathoni, H. (2019). Identifikasi Sikap peserta didik terhadap mata pelajaran fisika di Sekolah menengah Atas Negeri 5 Kota Jambi. Unnes Physics Education Journal. 8(1). 34-43.

[8] Tsai, MH, \& Tang, YC (2017). Learning Attitudes and Problem-Solving Attitudes For Blended Problem-Based Learning. Library Hi Tech, 35 (4), 622-635.

[9] Fraser, BJ (1981). Tosra: Test of Science-Related Attitudes: Handbook. Australian Council for Educational Research.

[10] Rodger Bybee, Bm (2009). Pisa 2006: An Assessment of Scientific Literacy. Journal of Research In Science Teaching, 865-883.

[11] Worokinasih, S., \& Potipiroon, W. (2019). Microfinance Repayment Performance of SMEs in Indonesia: Examining the Roles of Social Capital and Loan Credit Terms. The Journal of Behavioral Science, 14(1), 28-45.

[12] Vaishnav, Rs (2013). Learning Style and Academic Achievement of Secondary School Students. Voice of Research, 1 (4), 1-4.

[13] Larkin-Hein, T., \& Budny, Dd (2001). Research on Learning Style: Applications In The Physics

[14] Gilakjani, A. P. (2012). Visual, auditory, kinaesthetic learning styles and their impacts on English language teaching. Journal of studies in education, 2(1), 104-113.

[15] Miller P. (2001). Learning Styles: The Multimedia of The Mind. Educational Resources Information Centered 451 140 
[16] Higgins, E. T \& Kruglanski, A, W. (2000). Motivational Science Social and Personality Perspectives. Usa: Taylor \& Francis

[17] Guido, RMD (2013). Attitude and Motivation towards Learning Physics. International Journal of Engineering, 2 (11).

[18] Cresswel, John W. 2012. Educational Research: Planning, Conducting, and Evaluating Quantitative And Qualitative Research. New York: Pearson

[19] Cramer, D. Advanced quantitative data analysis. McGraw-Hill Education (UK). 2003.

[20] Cohen, L., Manion, L., \& Morrison, K. (2005). Research Methods in Education: Routledge.

[21] Gall. D, M. (2003). Education Research an Introduction Seventh Edition. Usa: Pearson Education. Inc.

[22] Oba, Fatoba, J \& Lawrence, Aladejana, A. (2014). Effects Of Gender On Student' Attitude To Physics In Secondary Schools In Oyo State, Nigeria. 10(7), 399-404.

[23] Crano, W. D., \& Prislin, R. (Eds.). (2011). Attitudes and Attitude Change. Psychology Press.

[24] Surip, R. (2016). The relationship among self-concept, reading attitude and reading comprehension achievement of single parented students of public junior high schools in district of Ilir Barat I Palembang. The Journal of English Literacy Education: The Teaching and Learning of English as a Foreign Language, 3(1), 12-26.

[25] Reid, J. M. (1987). The Learning Style Preferences Of Esl Students. Tesol Quarterly, 21(1), 87-111.

[26] Goodson, Tj (1994). Learning Style Preferences from East Asian Esl Students. Csa Linguistics And Language Behavior Abstracts.

[27] Kurniawan, D, A., Astalini., \& Anggraini,L. (2018). Evaluasi Sikap SMP Terhadap IPA di Kabupaten Muaro Jambi. Jurnal Ilmiah Didaktika: Media Ilmiah Pendidikan dan Pengajaran. 19(1), 123-139.

[28] Darmawangsa, R., Astalini., Kurniawan, DA (2018). Development of Instrument Attitudes of High School Students against Physics Subjects. Jpf: Journal of Physics Education, 6 (1), 107-114.

[29] Djamarah, SB Dan Zain, A. 2013. Teaching and Learning Strategies. Jakarta: Rineka Cipta .

[30] Choochom, O.,Sucaromana, U., \& Chavanovanich, J. (2019). A Model of Self-Development for Enhancing Psychological Immunity of the Elderly. The Journal of Behavioral Science. 14(1), 84-96.

[31] Widiadnyana, IW, Sadia, IW, \& Suastra, IW (2014). Influence of Discovery Learning Models on Understanding of Science Concepts and Scientific Attitudes of Junior High School Students. Indonesian Education Journal. Indonesian Education Journal, 4(1).

[32] Shah, Z., Mahmood, N., \& Harrison, C. (2013). Attitude towards Science Learning: An Exploration of Pakistani Students. Journal of Turkish Science Education, 1304-6020

[33] Hacieminoglu, E. (2016). Elementary School Students'
Attitude towards Science and Related Variables. International Journal of Environmental and Science Education, 11 (2), 35-52.

[34] Sukaesih, S. (2011). The Analysis of Scientific Attitudes and the Implementation of Practical-Based Learning Models. Journal of Educational Research, 28 (1).

[35] Stefan, M., \& Ciomos, F. (2010). The 8th and 9th Grades Students' Attitude towards Teaching and Learning Physics. Acta Didactica Napocensia, 3 (3), 7-14.

[36] Pell, T., \& Jarvis, T. (2001). Developing the Attitude to Science Scales for Use with Children of Ages from Five to Eleven Years. International Journal of Science Education, 23 (8), 847-862.

[37] Rosa, NM (2012). The Influence of Attitude on Chemistry and Self-Concept Of Chemical Learning Achievement. Scientific Journal of Mathematics Education Study Program of Indraprastha Pgri University, 2 (3), 218-226.

[38] Astalini, A., Kurniawan, D. A., Sulistiyo, U., Perdana, R., \& Susbiyanto, S. (2019). E-Assessment Motivation in Physics Subjects for Senior High School. International Journal of Online and Biomedic Engineering (iJOE), 15(11), 4-15.

[39] Sudibyo, Elegant Et Al. (2016). Development of Motivation Instrument Learning Physics: Questionnaire. Ipa Research Research Journal. 1 (1), 13-21.

[40] De Porter, Bobbi, And Hernacki, Mik. (2007). Quantum Learning. Translated By Alwiyah Adurrahman. Bandung: Kaifa Pt. Mizan Library.

[41] Tong, W, T., Islam, M, A., Low, W, Y., \& Choo, W, Y. (2019). Prevalence and Determinants of Pathological Internet Use among Undergraduate Students in a Public University in Malaysia. The Journal of Behavioral Science. 14(1), 63-83.

[42] Felder, Rm, \& Silverman, Lk (1988). Learning And Teaching Styles In Engineering Education. Engineering Education, 78 (7), 674-681.

[43] Keefe, J. \& Ferrell, B. (1990). Developing A Defensible Learning Style Paradigm, Educational Leadership, 10 